\title{
Research of Viral Agent in Free-living Pigeon Feces (Columba livia) in the City of São Paulo, SP, Brazil, for Transmission Electron Microscopy
}

\author{
Investigación de Agentes Virales en Heces de Palomas de Vida Libre (Columba livia) en \\ la Ciudad de São Paulo, SP, Brasil, Através de Miscroscopía Electrónica de Transmisión
}

"Catroxo, M. H. B. ; "Martins, A. M. C. R. P. F.; "* Petrella, S.; "Curi, N. A. \& "Melo, N.A.

CATroXo, M. H. B.; MARTINS, A. M. C. R. P. F.; PETREllA, S.; CURI, N. A.; MELO, N. A. Research of viral agents in freeliving pigeon feces (Columba livia) in São Paulo, SP, Brazil for transmission electron microscopy. Int. J. Morphol., 29(2):628-635, 2011.

SUMMARY: The pigeon feces are vehicle of diseases both for humans and other animal species. In these birds, the most important viral diseases of the digestive tract are transmitted by the paramyxovirus, adenovirus and coronavirus. Avian paramyxoviruses have been isolated from a variety of species of free living and domestic birds worldwide, with several symptoms and clinical signs and economic losses. Paramyxoviruses belong to the Paramyxoviridae family and Avulovirus genus that includes nine serotypes (APMV 1 to 9). Avian adenoviruses belong to the Adenoviridae family and Aviadenovirus genus. In pigeons, cause classical adenovirosis and necrotizing hepatitis. The respiratory and enteric tracts are common targets of coronavirus. They belong to the Coronaviridae family and to 3 a and $3 c$ groups. In this study, we described the presence of viral agents in free-living pigeon feces (Columba livia) from the city of São Paulo, Brazil. The feces were processed by negative staining technique (rapid preparation) for transmission electron microscopy. In this technique paramyxoviruses particles, pleomorphic, roughly spherical or filamentous, measuring 100 to $500 \mathrm{~nm}$ of diameter containing an envelope covered by spikes, with characteristic helical herring-bone-like nucleocapsid, measuring 15 to $20 \mathrm{~nm}$ in diameter, were visualized in 45 (79\%) out of 57 feces samples. In $2(3.5 \%)$ samples, paramyxovirus and adenovirus particles were simultaneously visualized. Adenovirus particles were isometric, spherical, characterized as "complete "or" empty ", measuring between 70 and 90 nm in diameter. Paramyxovirus and coronavirus particles were detected in $3(5.2 \%)$ samples. Coronaviruses were pleomorphic with a diameter of 75-160 nm containing a solar corona-shaped envelope, with projections of approximately $20 \mathrm{~nm}$ of diameter. Seven (12.3\%) samples were negative for viral particles.

KEYWORDS: Paramyxovirus, Adenovirus, Coronavirus, Pigeons, Transmission electron microscopy.

\section{INTRODUCTION}

Pigeons are birds of European origin found worldwide. Due to their high population growth, they act as important hosts in the spread of diseases in humans and other animal species, and transmission occurs via feces (Haag \& Gurdan, 1990; Orlandella et al., 1992, Toro et al. 1999). In nature, they play an important role as insect control and replanting of seeds eliminated by feces to the soil (Museu de Ciências Naturais).

In these species, the most important viral diseases of the digestive tract are transmitted by the paramyxovirus or adenovirus (Marlier \& Vindevogel, 2006) followed by coronavirus (Qian et al., 2006).
Avian paramyxoviruses are non-segmented single stranded RNA negative polarity, enveloped with helical symmetry of the nucleocapsid. Virions are pleomorphic, usually roughly spherical, $150 \mathrm{~nm}$ or more in diameter, but filamentous forms are common (Alexander et al., 1993).

They belong to the Mononegavirales order, Paramyxoviridae family, Paramixovirinae sub-family and Avulavirus genus which include 1-9 serotypes being Newcastle disease the serotype 1 (ICTV, 2009).

According to Alexander et al. (1991), the serotype 7 is most frequently isolated among Columbiformes.

\footnotetext{
" Laboratory of Electron Microscopy, Biological Institute of Sao Paulo, SP, Brazil.

*** Adolfo Lutz Institute, Sao Paulo, SP, Brazil.
} 
Avian paramyxoviruses have been isolated from a variety of free living species and domestic birds worldwide causing different symptoms and clinical signs resulting in economic losses (Leeuw \& Peeters, 1999).

Pigeons are particularly susceptible to avian paramyxovirus type 1 APMV-1 (Pennycott, 1994) and to other strains adapted to their organism (Ujvari et al., 2006), as the cNDVclassic and pigeon pAPMV 1 strains (Marlier \& Vindevogel).

Newcastle disease can be classified into velogenic, mesogenic and lentogenic depending on the pathogenicity of its strain. This can be viscerotropic, pneumotropic or neurotropic (Marlier \& Vindevogel).

The transmission of a velogenic strain in pigeons can occur in sick chickens during outbreaks (Vindevogel et al., 1972).

Regarding the velogenic cNDVstrain, the major symptoms are watery, and hemorrhagic diarrhea, conjunctivitis, rhinitis, dyspnea, congestion of the pharynx and larynx, tremors in the neck and wings, torticollis, paralysis and loss of healthy balance. The morbidity rate reaches $70 \%$ and mortality above $90 \%$ (Vindevogel et al., Ritchie et al., 1994).

Yet, in the infection with velogenic pAPMV-1 strain, with an incubation period 4-6 days to 3-4 weeks the respiratory symptoms are absent. The morbidity rate reaches 30 to $70 \%$ and mortality is less than $10 \%$ (Marlier \& Vindevogel).

The ingestion of contaminated feed or feces by pigeons can be a source of infection for other avian species, particularly chickens (Alexander et al., 1985).

In Brazil, other authors did not detect paramyxovirus in free-living pigeons (Carrasco, 2005; Sousa et al., 2010).

Regarding adenovirus, these agents induce in pigeons two distinct forms of infection, type 1 or classical adenovirosis and type 2 or necrotizing hepatitis (Marlier \& Vindevogel).

The type 1 affects mainly young pigeons (Duchatel et al., 2000), while type 2 affects birds aged 10 days to 6 years (Vereecken et al., 1998). In both types, the usually observed symptoms are vomiting, watery acute diarrhea, weight loss, anorexia and depression, with polyuria only in type 2 (Duchatel et al.).
The rapid spread of infection to other poultry, with mortality preceded by secondary bacterial infection and morbidity rates reaching $100 \%$ is specific to the classical adenovirosis (Duchatel et al.).

In type 2 or inclusion bodies hepatitis, the death of pigeons it was reported in 24 to 40 hours after the symptoms and mortality rate of 30 to $100 \%$ (Hess 1988 a, b; Vereecken et al.; Duchatel et al.; Wang \& Chang, 2000).

Transmission occurs through fecal-oral route and by aerosol (Ritchie et al.).

The avian adenovirus belongs to the Adenoviridae family and Aviadenovirus genus, composed of seven species of viruses (ICTV, 2009). Adenovirus is icosahedral in shape and non-enveloped particles of 70 to $90 \mathrm{~nm}$ in diameter. The capsid consists of 240 nonvertex capsomers called hexons, each 80-10 nm in diameter, and 12 vertex casomers (pentons), each with a protruding fiber from 9 to $77.5 \mathrm{~nm}$ in length. The genome is a linear molecule of double-stranded DNA 36-38 kb long (Davison et al., 2003). They replicate in the nucleus of the host cell producing basophilic intranuclear inclusions (Wu \& Nemerow, 2004).

On the other hand, avian coronaviruses belong to the Nidovirales order, Coronaviridae family, Gammacoronavirus genus and to $3 \mathrm{a}$ and $3 \mathrm{c}$ groups (Woo et al., 2009). The coronavirus has a pleomorphic to rounded morphology and is 90 to $200 \mathrm{~nm}$ in diameter. It is enveloped with club-shaped surface projections about $20 \mathrm{~nm}$ long. It contains a positive-strand RNA and replicates in the cytoplasm of the host cells (Cavanagh, 2005).

The respiratory and enteric tracts are common targets for coronaviruses (Miura \& Holmes, 2009).

Infectious bronchitis is the main disease caused by coronavirus in poultry and the infection results in significant economic losses to the commercial chicken industry (Pohuang et al., 2009). The virus was isolated in a flock of racing pigeons, carriers of infectious bronquitis, with clinical signs of ruffled feathers, dyspnea, mucus in the beak (Barr, 1988) and in pigeons with pancreatitis (Wu et al., 2005; Qian et al.). The detection of these agents in apparently healthy pigeons suggested the inclusion of a new member in the group 3 of the Gammacoronavirus genus (Jonassen et al., 2005).

The aim of this study was to investigate the 
presence of viral agents of free-living pigeon feces (Columba livia), using the negative staining technique (rapid preparation) for transmission electron microscopy, since these birds live in urban habitats, allowing greater proximity to humans and other birds from commercial farms.

\section{MATERIAL AND METHOD}

Description of the case. During the year 1999, freshly stool samples of 57 free-living pigeons (Columba livia) were collected, of which 50 adults and 7 young birds, apparently healthy, in urban areas of Sao Paulo.

After collection feces were stored on ice to be processed by negative staining technique (rapid preparation) for transmission electron microscopy at the Electron Microscopy Laboratory of the Biological Institute of Sao Paulo, SP, Brazil, to detect possible viral agents.

Negative staining technique (rapid preparation). In negative staining technique, 57 feces samples were suspended in phosphate buffer 0.1 M, pH 7.0. Drops of the obtained suspensions were placed in contact with metallic copper grids, stabilized with carbon supporting film of $0.5 \%$ in collodium amyl acetate. Next, the grids were drained with filter paper and negatively stained at $2 \%$ ammonium molybdate, pH 5.0 (Brenner \& Horne, 1959; Hayat \& Miller, 1990; Madeley, 1997.

\section{RESULTS}

Negative staining technique (rapid preparation). Under the transmission electron microscopy, paramyxovirus particles, pleomorphic, roughly spherical or filamentous, measuring 100 to $500 \mathrm{~nm}$ of diameter containing an envelope covered by spikes, with herring-bone like nucleocapsid, measuring 15 to $20 \mathrm{~nm}$ in diameter were visualized in the $45(79 \%)$ out of 57 feces samples (Fig. 1).

The 45 stool samples were pasty with green or brown color.

In $2(3.5 \%)$ stool samples, paramyxovirus and adenovirus particles were simultaneously observed. The adenovirus particles were seen to be isometric, spherical, non-enveloped, containing capsid of icosahedral symmetry, particles characterized as "complete" and "empty", measuring between 70 and $90 \mathrm{~nm}$ in diameter (Figs. 2, 3).

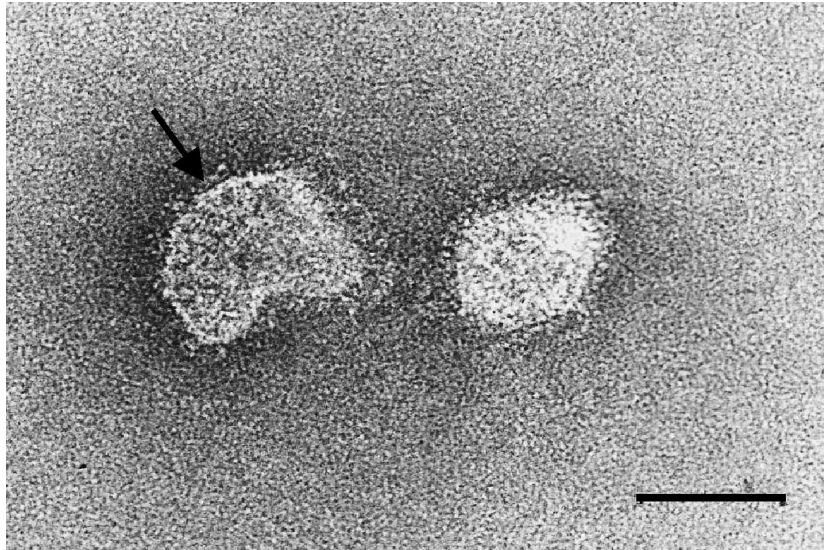

Fig. 1. Negatively stained paramyxovirus particles, pleomorphic, roughly spherical, containing an envelope covered by spikes (arrow). Bar: 80nm.

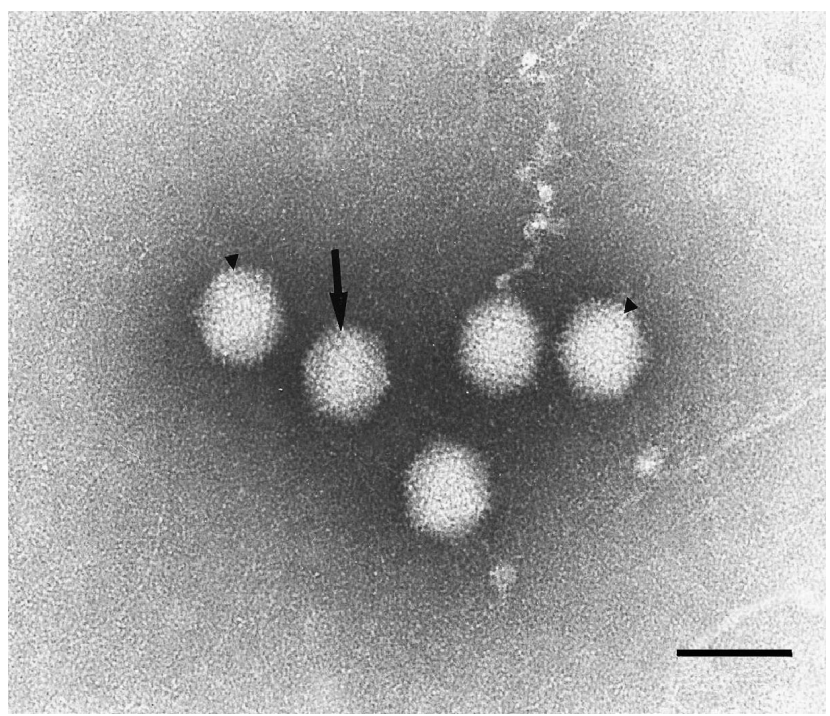

Fig. 2. Negatively stained adenovirus particles, showing a hexagonal shape (arrow) with distinct closely packed capsomers (arrow head). Bar: $95 \mathrm{~nm}$.

In these two samples, watery feces, yellowish and with mucus was observed.

In $3(5.2 \%)$ samples, the presence of paramyxovirus and coronavirus particles was observed (Fig. 5). The coronavirus was pleomorphic with a diameter of 75-160 nm containing a solar corona-shaped envelope, with projections of approximately $20 \mathrm{~nm}$ of diameter (Fig. 4).

These stool samples were watery and yellowish.

Furthermore, no type of particle was detected in 7 $(12.3 \%)$ analyzed stool samples. 


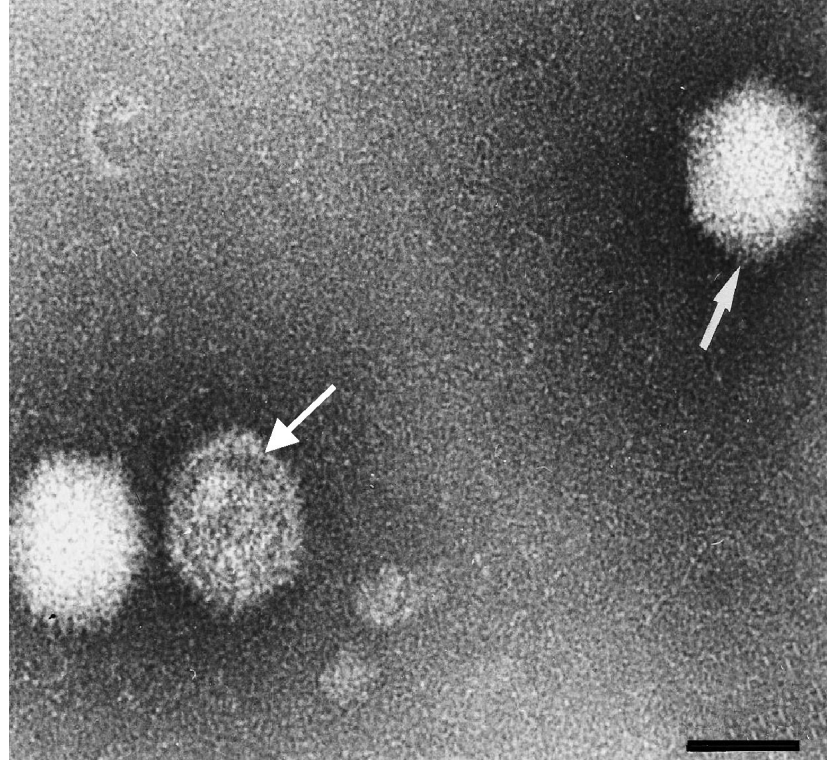

Fig. 3. Negatively stained adenovirus particles, exhibiting the hexagonal outline formed by the distinct capsomers (arrow). Bar: $60 \mathrm{~nm}$.

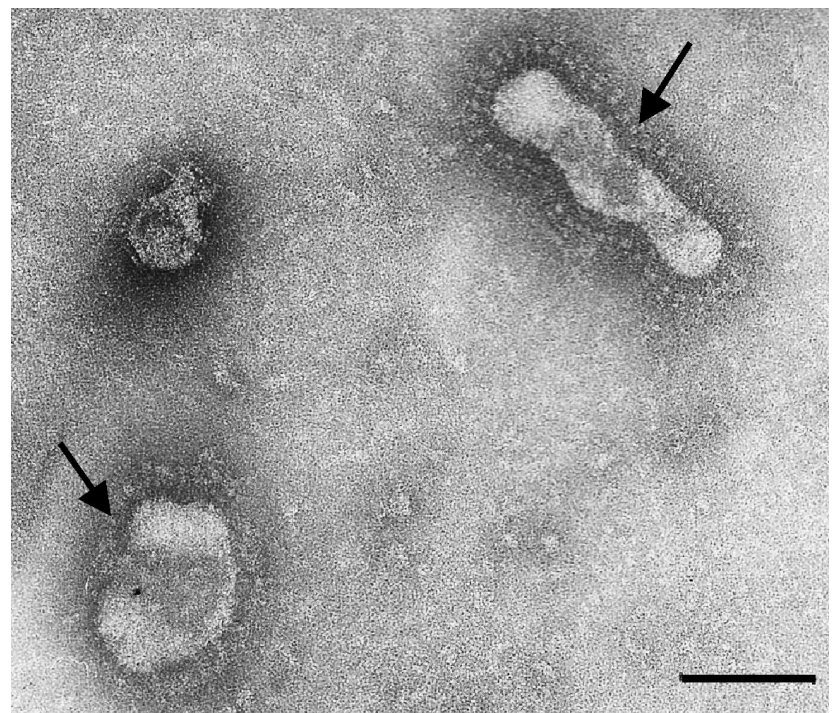

Fig. 4. Negatively stained pleomorphic coronavirus particles, with a solar corona-shaped envelope (arrow). Bar: $120 \mathrm{~nm}$.

\section{DISCUSSION}

In this study, using the negative staining technique (rapid preparation) for transmission electron microscopy, we observed typical paramyxovirus particles in 45 (79\%) out of 57 stool samples from free-living pigeons (Columba livia).

These results are in accordance with data in the literature showing particles with similar morphology in pigeons (Gough \& Alexander, 1983), owls (Catroxo et al.,

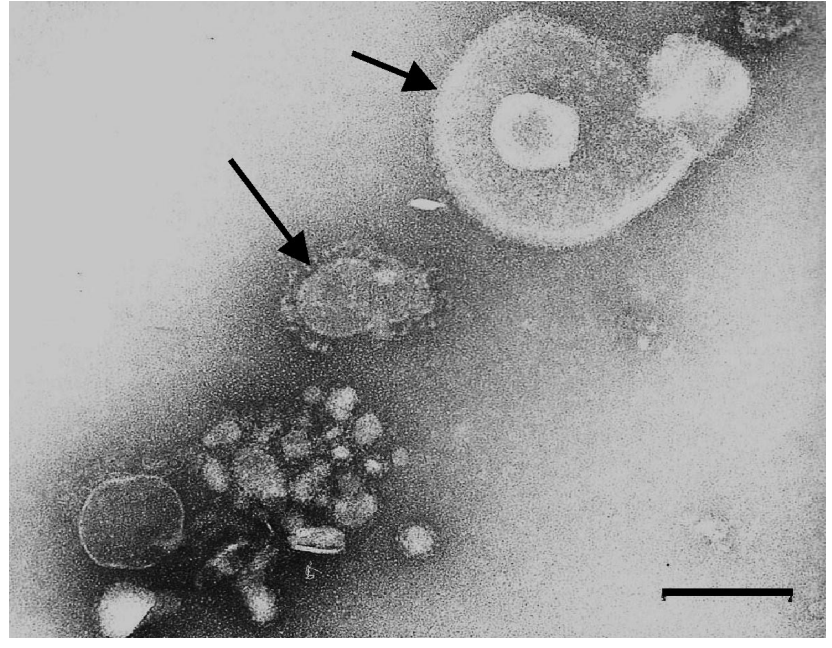

Fig. 5. Negatively stained showing the simultaneos presence of coronavirus (big arrow) and paramyxovirus (minor arrow) particles. Bar: $110 \mathrm{~nm}$.

2010), ducks (Chang et al., 2001) and Gouldian Finch (Zhang et al., 2006).

The paramyxovirus of the Newcastle Disease (PMV1) was also detected in pigeons by serological techniques in organ fragments (Shirai et al., 1986; Meulemans et al., 2002; Mushtaq et al., 2006) and blood (Toro et al.; Tsai \& Lee, 2006) as well as by molecular techniques (Collins et al., 1989; Zanetti et al., 2001, Aldous et al., 2004).

Later, other researchers using the same techniques were not successful in obtaining the PMV-1 in free-living pigeons (Carrasco; Lillehaug et al., 2005; Sousa et al.).

A study by Tsai \& Lee in healthy birds from poultry farms, showed the presence of PMV-2 in these birds. Similarly, the birds studied by us were apparently healthy.

Additionally, experiments demonstrate that PMV-7 type, considered non-pathogenic, has been frequently isolated among Columbiforms (Gough \& Alexander; Alexander et al., 1991; Ritchie et al.). Instead, Toro et al. did not detect the PMV-7 in samples of free-living birds.

Free-living birds can act as carriers and reservoirs of avian pathogens (Sousa et al.).

In this study, concomitant presence of particles of adenovirus and paramyxovirus samples was found in $2(3.5 \%)$ samples.

Wang \& Chang observed by the negative staining technique, the presence of typical adenovirus particles in cell 
culture supernatant of pigeon tissue. Also, it was demonstrated in pigeons in ultrathin sections of liver (Goryo et al. 1988; Sagartz \& Swayne, 1991) intestine (Bergmann \& Kiupel, 1982; Wada et al., 1995) and in cell cultures (Takase et al., 1990), intranuclear inclusions bodies containing such particles.

Additionally, analysis of liver fragments by PCR technique (Freick et al., 2008) and blood by serological techniques (Tsai \& Lee) enabled diagnosis of these viruses in pigeons.

In our study, we found that $2(3.5 \%)$ stool samples positive for adenovirus and paramyxovirus were greenish, pasty and with mucus.

These characteristics of loose stools was also reported in pigeons with inclusion body hepatitis (Goryo et al., 1988; Dorrestein et al., 1992; Ritchie \& Carter, 1995).

Differences in clinical signs and pathology associated with adenovirus infections in pigeons suggest that more than one virus with varied organ affinity may infect these birds (Ritchie et al.)

The negative staining technique is considered effective because it is simple and rapid to diagnose viruses in biological samples (Doane \& Anderson, 1987) besides requiring a small amount of sample (Almeida, 1983), allow detection of different viral particles in the same sample (Fenner et al., 1992) and excludes the possibility of false positives (Ueda et al., 1998; Hazelton \& Gelderblont, 2003), advantages with which we agree. However, according to Freick et al., these techniques are laborious and time consuming especially in the detection of adenovirus.

Ritchie et al. confirm that additional studies are needed to elucidate better correlation between the adenovirus and pigeons as hosts.

The observation of typical particles of paramyxovirus and coronavirus in $3(5.2 \%)$ out of 57 analyzed samples, corroborates with other authors who have found coronavirus in owls (Catroxo et al., 2010), quail (Circella et al., 2007) and green-cheeked (Gough et al., 2006).

We observed that three stool samples were positive for coronavirus and paramyxovirus and were yellowish and watery.

In turkey, coronavirus was associated with pronounced enteric tropism (Nagaraja \& Pomeroy, 1997) and quail to an enteric syndrome (Circella et al.).
Coronaviruses have also been identified in a flock of racing pigeons with infectious bronchitis which showed signs of ruffled feathers, dyspnea, mucus in the beak (Barr) and pancreatitis (Qian et al.).

Other experiments showed in apparently healthy rock doves, another type of coronavirus genetically distinct from those found in infectious bronchitis (Jonassen et al.).

Sousa et al. explain that the condition of carriers of infectious bronchitis in wild and exotic birds is justified by the interaction between species or its close relationship to commercial poultry farms.

Whereas free-living pigeons are potent agents of viral hosts, we believe that frequent monitoring through techniques such as electron microscopy, contributes to the protection of public health and prevention of diseases in commercial poultry farms and preservation of the species (Columba livia) studied by us.

The findings of the present study constitute the first report on presence of these viruses in this avian species.

CATROXO, M. H. B.; MARTINS, A. M. C. R. P. F.; PETRELLA, S.; CURI, N. A.; MELO, N. A. Investigación de agentes virales en heces de palomas de vida libre (Columba livia) en la ciudad de São Paulo, SP, Brasil através de microscopía electrónica de transmisión. Int. J. Morphol., 29(2):628-635, 2011.

RESUMEN: Los heces de las palomas constituyen vehículos de enfermedades importantes, tanto para el Hombre como para otras especies animales. En estas aves, las enfermedades virales más importantes del tracto digestivo son transmitidas por los paramixovirus, adenovirus y coronavirus. Paramixovirus aviario, en todo el mundo, ha sido aislado de una variedad de especies de vida libre y de aves domésticas, que causan variados síntomas y señales clínicas con pérdidas económicas. El Paramixovirus pertenece a la familia Paramyxoviridae y al género Avulavirus que incluye nueve serotipos (APMV 1 a 9). Adenovirus aviario pertenece al género de la familia Adenoviridae y género Aviadenovirus. En las palomas, causan la adenovirosis clásica y la hepatitis necrotizante. El tracto respiratorio y entérico son los albos comunes de los coronavirus. Ellos pertenecen a la familia Coronaviridae y a los grupos 3a y 3c. En este trabajo, se describe la presencia de agentes virales en las heces de palomas de vida libre (Columba livia) en la ciudad de São Paulo, Brasil. Las heces se procesaron para la técnica de microscopía electrónica de transmisión, a través de la técnica de contrastación negativa (preparación rápida). A través de esta técnica fueron visualizadas las partículas de paramixovirus, pleomórficas, más o menos esféricas o filamentosas, de 100 a $500 \mathrm{~nm}$ de diámetro que contiene un envoltorio cubierto con espículas, con nucleocapside con características helicoidales, midiendo de 15 a $20 \mathrm{~nm}$ de diámetro en 45 (79\%) de 57 muestras. En $2(3,5 \%)$ muestras, fueron observadas simultáneamente partí- 
culas de paramixovirus y de adenovirus. Las partículas de adenovirus eran isométricas, esféricas, caracterizadas como "completa " o "vacía ", midiendo entre 70 y 90 nm de diámetro. Fueron analizadas en tres muestras $(5,2 \%)$ las partículas de paramixovirus y coronavirus. Los coronavirus son pleomórficos, con un diámetro de 75 a $160 \mathrm{~nm}$, que contiene un capa en forma de corona solar con proyecciones de aproximadamente $20 \mathrm{~nm}$ de diámetro. Siete $(12,3 \%)$ muestras fueron negativas para las partículas virales.

PAlabras ClaVE: Paramoxivirus; Adenovirus; Coronavirus; Palomas, Microscopía Electrónica de Transmisión.

\section{REFERENCES}

Aldous, E. W.; Fuller, C. M.; Mynn, J. K. \& Alexander, D. J. A molecular epidemiological investigation of isolates of the variant avian paramyxovirus type 1 virus (PPMV1) responsible for the 1978 to present panzootic in pigeons. Avian Pathol., 33(2):258-69, 2004.

Alexander, D.J.; Manvell, R.J.; Collins, M.S. \& Brockman, S.J. Evaluation of relationships between avian paramyxoviruses isolated from birds of the family Columbidae. Arch. Virol., 116:267-76, 1991.

Alexander, D.J.; Parsons, G.; Manvell, R.J. \& Sayers, A.R. Characterization of avian paramyxovirus type 1 infections of racing pigeons in Great Britain during 1983 to 1990. In: Proceedings of the Commission of the European Communities Meeting on Virus Diseases of Poultry-New and Evolving Pathogens. Brussels, Belgium. p.65-75, 1993.

Alexander, .J.; Wilson, G.W.; Russel, P.H.; Lister, S.A. \& Parsons, G. Newcastle disease outbreaks in fowl in Great Britain during 1984. Vet. Rec., 117(17):429-34, 1985.

Almeida, J.D. Uses and abuses of diagnostic electron microscopy. Curr. Top. Microbiol. Immunol., 104:147$158,1983$.

Barr, D.A. isolation of infectious bronchitis virus from a flock of racing pigeons. Aust. Vet., 65:228, 1988.

Bergmann, V. \& Kiupel, H. Einschlusskörperchen enteritis bei Tauben, hervorgerufen durch Adeno- und Parvovivus. Arch. Exper. Vet. Med., 36:445-53, 1982.

Brenner, S. \& Horne, R. W. A negative staining method for high resolution electron microscopy of viruses. Biochem. Biophys. Acta, 34:103, 1959.
Carrasco, A.O.T. Infecção experimental de pombos com estirpes do vírus da doença de Newcastle de baixa e alta patogenicidade. 2005. 71f. Dissertação (Mestrado) - Faculdade de ciências Agrárias e Veterinárias, Universidade Estadual Paulista, Jaboticabal, SP., 2005.

Catroxo, M. H. B.; Taniguchi, D. L.; Melo, N. A.; Milanelo, L.; Petrella, S.; Alves, M.; Martins, A.M.C. R.P.F. \& Rebouças, M. M. Viral research in Brazilian owls (Tyto alba and Rhinoptynx clamator) by transmission electron microscopy. Int. J. Morphol., 28(2):627-36, 2010.

Cavanagh, D. Coronaviruses in poultry and other birds. Avian Pathol., 34(6):439-48, 2005.

Chang, P.C.; Hsieh, M.L.; Shien, J.H.; Graham, D.A.; Lee, M.S. \& Shied, H.K. Complete nucleotide sequence of avian paramyxovirus type 6 isolated from ducks. $J$. Gen. Virol., 82:2157-68, 2001.

Circella, E.; Camarda, A.; Martella, V.; Bruni, G.; Lavazza, A. \& Buonavoglia, C. Coronaviruses associated with an enteric syndrome on a quail farm. Avian Pathol., 36(3):251-8, 2007.

Collins, M. S.; Alexander, D. J.; Brockman, S.; Kemp, P. A.\& Manvell, R. J. Evaluation of mouse monoclonal antibodies raised against an isolate of the variant paramyxovirus type 1 responsible for the current panzootic in pigeons. Arch. Virol., 104:53-61, 1989.

Davison, A.J.; Benko, M. \& Harrach, B. Genetic content and evolution of adenoviruses. J. Gen. Virol., 84:2895908, 2003.

Doane, F.W. \& Anderson, M. Electron microscopy in diagnostic virology - A pratical guide and atlas. Cambridge University Press, Cambridge, 1987,178p.

Dorrestein, G.M.; van der Hage, M.H.; Burger, L. \& Kouwenhoven, B. Adenovirus inclusion body hepatitis: a new pigeon disease? In: Proceedings of the Seventh Symposium on Avian Diseases, Munich, Germany, 1992, pp 7-14.

Duchatel, J.P.; Marlier, D.; Jauniaux, T. \& Vindevogel, H. Les infections par ade'novirus chez le pigeon. Annales de Medecine Veterinaire, 144:13-7, 2000.

Fenner, F.; Bachmann, P. A.; Gibbs, E. P. J.; Murphy, F. A.; Studdert, M. J. \& White, D. O. Virología Veterinaria. Zaragoza, Acribia, 1992. 
Freick, M.; Muller, H. \& Raue, R. Rapid detection of pigeon herpesvirus, fowl adenovirus and pigeon circovirus in young racing pigeons by multiplex PCR. J. Virol. Methods., 148:226-31, 2008.

Goryo, M.; Ueda, Y.; Umemura, T.; Haruna, A. \& Itakura, C. Inclusion body hepatitis due to adenovirus in pigeons. Avian Pathol., 17:391-401, 1988.

Goryo, M.; Ueda, Y.; Haruna, A,; \& Itakura, C. Inclusion body hepatitis due to adenovirus in pigeons. Avian Pathol., 17:391-401, 1988.

Gough, R.E. \& Alexander, D.J. Isolation and prelimirary characterization of a paramyxovirus from collared doves (Streptopelia decaocto). Avian Pathol., 12:12534, 1983.

Gough, R.E.; Drury, S.E.; Culver, F.; Britton, P. \& Cavanagh, D. Isolation of a coronavirus from a greencheeked Amazon parrot (Amazon viridigenalis cassin). Avian Pathol., 35(2):122-126, 2006.

Haag, D. \& Gurdan, P. Über den hygienischen Zustand der Strassentauben in Bassel. Swiss Vet. J., 7:19-21, 1990.

Hayat, M. A. \& Miller, S. E. Negative Staining. Mc. GrawHill Publ. Company., 1990. 235p.

Hazelton, P. R. \& Gelderblom, H. R. Electron microscopy for rapid diagnosis of emerging infectious agents. Emerg. Infect. Dis.,9(3):294-303, 2003.

Hess, M.; Prusas, C.\& Monreal, G. Growth analysis of adenoviruses isolated from pigeons in chicken cells and serological characterization of the isolates. Avian Pathol., 27:196-9, 1998a.

Hess, M.; Prusas, C.; Vereecken, M. \& De Herdt, P. Isolation of fowl adenoviruses serotype 4 from pigeons with hepatic necrosis. Berliner und Munchener Tierärztliche Wochenschrift 111:140-2, 1998b.

ICTV Virus Taxonomy. 2009. International Committee on Taxonomy of viruses. Available: http;// www.ictvonline.org/virusTaxonomy.asp.

Jonassen, C.M.; Kofstad, T.; Larsen, I.-L.; Lovland, A.; Handeland, K.; Follestad, A. \& Lillehaug, A.. Molecular identification and characterization of novel coronaviruses infecting graylag geese (Anser anser), feral pigeons (Columbia livia) and mallards (Anas platyrhynchos). J. Gen. Virol., 86:1597-607, 2005.
Qian, D.H.; Zhu, G.J.; Wu, L.Z. \& Hua, G.X. Isolation and characterization of a coronavirus from pigeons with pancreatitis. Am. J. Vet. Res., 67(9):1575-9, 2006.

Leeuw, O. \& Peeters, B. Complete nucleotide sequence of Newcastle disease virus: evidence for the existence of a new genus within the subfamily Paramyxovirinae. $J$. Gen. Virol., 80:131-6, 1999.

Lillehaug, A.; Jonassen, M. C.; Bergsjo, B.; Hofshagen, M.; Tharaldsen, J.; Nesse, L. L.\& Handeland, K. Screening of feral pigeon (Columba livia), mallard (Anas platyrhynchos) and graylag goose (Anser anser) populations for Campylobacter spp., Salmonella spp., Avian Influenza virus and avian paramyxovirus. Acta vet. Scand., 46:193-202, 2005.

Madeley, C. R. Electron microscopy and virus diagnosis. J. Clin. Pathol., 50:454-6, 1997.

Marlier, D. \& Vindevogel, H. Viral infections in pigeons. Vet. J., 172:40-51, 2006.

Meulemans, G. \& van den Berg, T.P.; Decaesstecker, M.; M. Boschmans, M. Evolution of pigeon Newcastle disease virus strains. Avian Pathol., 31:515-19, 2002.

Miura, T. \& Holmes, K. V. Host-pathogen interactions during coronavirus infection of primary alveolar epithelial cells. J. Leukocyte Biol., 86:1145-51, 2009.

Museu de Ciências Naturais. Pombos-Domésticos. www.fzb.rs.gov.br/museu/downloads/pombosdomesticos.pdf. 2007.

Mushtaq, I.; Rizvi, F.\& Ullah, M.S. Effect of pigeon origin Newcastle disease virus on various liver enzymes and associated pathological changes in experimentally infected pigeons. Pakistan Vet. J., 26(4):171-5, 2006.

Nagaraja K.V. \& Pomeroy B.S. Coronaviral enteritis of turkeys (bluecomb disease). In: Diseases of Poultry. Eds. B.W. Calnek, H.J.Barnes, C.W. Beard, W.M. Reid and H.W. Yoda. $10^{\text {th }}$ Edn., pp. 686-692. Iowa, Iowa State Univeristy Press, 1997.

Orlandella, B.M.; Catanella, N.; Foti, M.; Leopizzi, M.; Daidone, A.; 'D'aura, D. \& Orlandella, V. Riserche sul ruolodel colombo nella diffusione di agenti patogeni zoonosici III.: le salmonelle. Indagini nella citta di Messina. Acta Med. Vet., 38:123-46, 1992.

Pennycott, T.W. Avian paramyxovirus type-I in feral pigeons. Vet Rec., 134(21):560, 1994. 
Pohuang, T.; Chansiripornchai, N.; Tawatsin, A. \& Sasipreeyajan, J. Detection and molecular characterization of infectious bronchitis virus isolated from recent outbreaks in broiler flocks in Thailand. $J$. Vet. Sci., 10(3):219-23, 2009.

Ritchie, B.W. \& Carter, K. Avian viruses: Function and control. Lake Worth, Florida, Ed. Publishing Incorporated, 1995. pp.285-311.

Ritchie, B. W.; Harrison, G. J. \& Harrison, L. R. Avian Medicine: Principles and application. Florida, Ed. Wingers Publishing Inc., 1994. pp.865-74.

Sagartz, J.E. \& Swayne, .E. Inclusion body hepatitis in a pigeon associated with an adenovirus. J. Zoo Wildl. Med., 22(4):485-7, 1991.

Shirai, J.; Tsukamoto, K. \& Hihara, H. Newcastle disease viruses isolated from racing pigeons in Japan. Jpn. J. Vet. Sci., 48(6):1091-5, 1986.

Sousa, E.; Werther, K. \& Berchieri Júnior, A. Assessment of Newcastle and infectious bronchitis pathogens, and Salmonella spp. in wild birds captured near poultry facilities. Arq. Bras. Med. Vet. Zootec., 62(1):219-23, 2010.

Takase, K.; Yoshinaga, N.; Egashira, T.; Uchimura, T. \& Yamamoto, M. Avian adenovirus isolated from pigeons affected with inclusion body hepatitis. Jpn. J. Vet. Sci., 52(2):207-15, 1990.

Toro, H.; Saucedo, .C; Borie, C.; Gough, R.E. \& Alcaíno, H. Health status of free-living pigeons in the city of Santiago. Avian Pathol., 28:619-23, 1999.

Tsai, H.-J. \& Lee, C.-Y. Serological survey of racing pigeons for selected pathogens in Taiwan. Acta Vet. Hung., 54(2):179-89, 2006.

Ueda, M.; Tanaka, H.; Kisielius, J.J.; Pires, M.F.C. \& Weigl, D.R. Importance of electron microscopy and its contribution to viral diagnosis. J. bras. Soc.Virol., 3(12):9-36, 1998.

Ujvari, D. Complete nucleotide sequence of IT-227/82, an avian paramyxovirus type- 1 strain of pigeons (Columba livia). Virus Genes, 32:49-57, 2006.

Vereecken, M.; de Herdt, P. \& Ducatelle, R. Adenovirus infections in pigeons: a review. Avian Pathol., 27: 3338,1998 .
Vindevogel, H.; Meulemans, G.; Halen, P. \& Schyns, P. Susceptibility of the adult carrier pigeons to Newcastle disease virus. Ann. Res. Vet., 3:519-32, 1972.

Wada, Y.; Kondo, H.; Nakazawa, M. \& Kubo, M. Natural infection with attaching and effacing Escherichia coli and adenovirus in the intestine of a pigeon with diarrhea. Vet. Med. Sci., 57(3):531-3, 1995.

Wang, C.-.H. \& Chang, C.-M. Pathogenicity and gene analysis of an adenovirus from pigeons with inclusion body hepatitis. J. Vet. Med. Sci., 62(9):989-93, 2000.

Woo, P. C. Y.; Lau, S. K. P.; Huang, Y. \& Yuen, K-Y. Coronavirus diversity, phylogeny and interspecies jumping. Exp. Biol. Med.(Maywood)., 234(10):1117$27,2009$.

Wu, E., \& Nemerow, G. R. Virus yoga: the role of flexibility in virus host cell recognition. Trends Microbiol., 12(4):162-9, 2004.

Wu, Z.-L.; Qian, H.-D. \& Yao, C.-B. Isolation and identification of pigeon coronavirus. J. Shangai Jiaotong Univ., 23(3):275-9, 2005.

Zanetti, F.; Mattiello, R.; Garbino, C.; Kaloghlian, A.; Terrera, M.V.; Boviez, J.; Palma, E.; Carrillo, E. \& Berinstein, A. Biological and molecular characterization of a pigeon paramyxovirus type-1 isolate found in Argentina. Avian Dis., 45:567-71, 2001.

Zhang, G.O.; Zhao, J.X.; Wang, H.W.; Yang, A.M.; Bu, C.Y. \& Wang, M. Isolation, identification, and comparison of four isolates of avian paramyxovirus serotype 2 in China. Avian Dis., 50(3):386-90, 2006.

\section{Correspondence to: \\ Prof. Dr. Marcia Catroxo \\ Electron Microscopy Laboratory \\ Research and Development Center in Animal Health \\ Biological Institute of São Paulo \\ Av. Conselheiro Rodrigues Alves, 1252 \\ CEP 04014-002 \\ Vila Mariana \\ São Paulo, SP \\ BRAZIL}

Email: catroxo@biologico.sp.gov.br

Received: 04-01-2011 Accepted: 28-02-2011 